\title{
Islam di Indonesia dan Fenomena Disintegrasi Bangsa
}

\author{
Yusdani
}

This article traces the problem of disintegration that emerges in Indonesia recently. How to solve this problem from Islamic political viewpoint? Because of this, the leaders of muslim political organization in Indonesia should participate in solving the problem toward reformulating the theological ideas as a basis for political view and action in Indonesia, redefining the political ideas in the context of Indonesia, and to reformulate the strategy to moslem's struggle in modern indonesia.

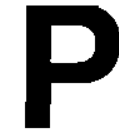
ada umumnya orang Islam percaya akan sifat Islam yang universal dan holistik. Sebagai sebuah instrumen untuk memahami sebuah kehidupan, Islam sering dianggap sebagai sesuatu yang lebih daripada sekedar sebuah agama. Banyak yang melihatnya sebagai "masyarakat sipil" 1, "peradaban yang komplit", atau "agama dan negara". ${ }^{3}$ Formulasi-for-

' Muhammad Iqbal, 1972. The Reconstruction of Religious Thought in Islam, Lahore: Muhammad Ashraf.

2 H.A.R. Gibb,. (Ed.). 1932. Moslem Whither Islam: A Survey of Modern Movements in the World, London : Victor Gollancz Ltd.

${ }^{3}$ Muhammad Yusuf Musa, Nizam alHukm fi al-/siam, Cairo: Dar al-Kitab al-Arabi; 1963 ), hlm. 18 dan Taha Abd. al-Baqi Surur, Dawla al-Qur'an, Cairo: Dar Nadha Misr, 1972, h.lm. 80. mulasi semacam ini pada dasarnya merupakan pandangan umum bahwa Islam itu lebih dari sekedar sistem ritus. Lebih spesifik lagi, Islam tidak mengenal sekat pemisah antara yang bersifat spiritual dan temporal. Sebaliknya, Islam memberikan panduan etis bagi setiap lapangan kehidupan.

Sementara komunitas Islam percaya akan sifat universalitas dan holistik Islam, tetapi bagaimana keluasan ajaran tersebut diartikulasikan dalam kehidupan bermasyarakat, berbangsa dan bernegara merupakan sesuatu yang problematis. Ada sementara pihak yang cenderung memahami sifat holistik Islam secara organik, ${ }^{4}$

${ }^{4}$ Bahtiar Effendy. "Islam dan Negara Transformasi Pemikiran dan Praktek Politik Islam di Indonesia." dalam Prisma, 5 Mei 1995. him. 6. 
dalam pengertian bahwa hubungan Islam dengan segala aspek kehidupan harus dalam bentuknya yang legal dan formal. Sedangkan di pihak lain, ada yang melihat totalitas ajaran Islam dalam dimensinya yang lebih substansif, mengutamakan - isi daripada bentuk- menjadi acuan utama dalam kehidupan sosial masyarakat.

\section{Arus Sistem Politik Dinastik Otoriter dalam Sejarah}

Dunia Islam mengalami kesulitan dalam upaya mendamaikan dua kecenderungan yang sangat berbeda tersebut yang memungkinkan menciptakan sintesa yang harmonis antara Islam dan politik, terutama sejak pudarnya kolonialisme Barat pada pertengahan abad ke-20. Di Indonesia, hubungan antara Islam dan Negara (politik) tak jauh berbeda dengan apa yang dialami oleh kawasan dunia Islam lainnya, seperti Turki, Mesir, Sudan, Maroko, Pakistan, Malaysia, Aljazair, dan sebagainya. Di wilayah-wilayah itu, hubungan antara Islam dan negara ditandai dengan ketegangan politik, kalau bukan permusuhan. Menyadari posisi Islam sebagai agama mayoritas di negaranegara itu, kenyataan demikjan merupakan fenomena yang mengherankan. Karena itu, banyak pengamat politik Islam mempersoalkan apakah Islam sesuai dengan sistem politik masyarakat yang konsep negara-bangsa (nation state) merupakan salah satu unsur utamanya? ${ }^{5}$.

Di antara ironi sejarah bila Islam dikaitkan sebagai agama terbuka adalah perilaku pemimpin politik umat di berbagai

${ }^{5}$ Leonard Binder, 1963. Religion and Politics in Pakistan, Berkeley dan Los Angeles: University of California Press. negara Muslim, yang justru memakai sistem tertutup. Hanya satu dua saja negara Muslim yang dengan mantap telah menerapkan sistem politik demokrasi dengan menghormati sepenuhnya asas kedaulatan rakyat. Fenomena ini sudah tentu mempunyai akar yang sangat jauh dalam rahim sejarah umat Islam. Yang jelas, tradisi ketertutupan dalam politik tersebut sama sekali bukan berasal dari generasi pemimpin muslim awal.

Budaya ketertutupan itu berkaitan dengan diperkenalkannya sistem politik dinastik, yang notabene anti Islam, ke dalam sistem politik muslim sejak masa Dinasti Umayyah. ${ }^{6}$ Sistem ini kemudian melanggeng selama berabad-abad, sementara sampai sekarang sisanya masih dapat dilihat pada beberapa negara muslim. Dari perkembangan tersebut, tidaklah menghērankan jika kemudian didapati kenyataan bahwa dari dunia Islam, selama kurun waktu yang begitu panjang hampirhampir tidak mampu melahirkan teori-teori politik demokratik, yang membela prinsipprinsip keterbukaan dalam bernegara.

Para yuris muslim abad pertengahan, sekalipun mereka sangat "concern" terhadap masalah-masalah keadilan, tidak seorang pun di antara mereka yang mampu mengartikulasikan prinsip "syura" menjadi sebuah sistem politik yang membela keterbukaan. Arus sejarah dinastikotoriter begitu lama mendominasi perpolitikan di dunia Islam. Oleh sebab itu, tidaklah mengherankan mengapa sebagian bangsa-bangsa muslim yang memperoleh kemerdekaan pasca-Perang Dunia II

${ }^{6}$ Ahmad Syafii Ma'arif, 1995. Membumikan Islam, Yogyakarta : Pustaka Pelajar, him. 159. 
Topik : Islamn di Indonesia dan Fenomena Disintegrasi Bangsa, Yusdani

bingung dalam memilih dan menetapkan sistem politik yang harus mereka laksanakan; demokrasi, kerajaan, atau sistem otoriter. Sampai saat ini masalah tersebut belum pernah diselesaikan secara tuntas dan meyakinkan, baik secara teori maupun praktik.

Dengan segala kelemahan dan kekurangannya, bangsa Muslim Indonesia sejak masa pergerakan nasional sudah memilih sistem politik demokrasi sebagai wahana yang terbaik untuk membumikan cita-cita kemerdekaan. Pilihan ini dapat dinilai sebagai pilihan terbaik, tepat, dan benar. Oleh karena itu, organisasi-organisasi sosio-keagamaan dan sosio-politik Islam adalah sebagai pelopor utama bagi cita-cita demokrasi. "Almarhum" partai Masyumi dikenal orang sebagai partai mati dalam keadaan syahid dalam membela dan mempertahankan demokrasīi Syahid dalam menghadapi sistem politik otoriter yang dipaksakan melalui mekanisme Demokrasi Terpimpin Orde Lama dan Demokrasi Pancasila Orde Baru yang dipaksakan beberapa puluh tahun silam.

Akan tetapi suatu hal yang memprihatinkan bahwa dalam sejarah politik bangsa Indonesia yang mayoritas muslim dan terkenal berbudaya santun itu dua kali peristiwa suksesi nasional - dari Orde Lama ke Orde Baru dan dari Orde Baru ke reformasi diwarnai pertumpahan darah bahkan sekarang ini cenderung anarki dan disintegratif dengan ditandai beberapa wilayah provinsi ingin melepaskan diri dari Negara Kesatuan Republik Indonesia, seperti kasus Papua dan Aceh dan lainlain. Inilah salah satu akibat dan bahaya bangsa yang hidup dalam alam politik demokrasi yang semu dan jauh dari nilainilai moralitas dan etika politik kemanusiaan.

\section{Etika Pembangunan Masyarakat dalam Perspektif Islam}

"Tidak diragukan lagi", tulis Fazlur Rahman" bahwa tujuan sentral Alquran adalah untuk menciptakan tata sosial yang anggun dan hidup di muka bumi, yang adil dan didasarkan pada etika. ${ }^{7}$ Dalam perspektif Islam apakah individu yang lebih penting ataukah masyarakat, tidak menjadi soal. Yang jelas antara individu dan masyarakat berkaitan. Umpamanya individu tanpa masyarakat (a societiless individual) ${ }^{8}$ tidak akan ditemukan di muka bumi ini. Yang amat ditekankan Islam ialah perlunya keamanan ontologis (ontological security) bagi binaan sebuah masyarakat dan peradaban yang prinsip moral-transendental menjadi asasnya yang utama. Tanpa asas moral yang kukuh ini jangan diharapkan bahwa keadilan menjadi cita-cita abadi umat sejagat akan terwujud. Konsep masyarakat mekanistik (a mechanistic conception of society tidak memberi peluang kepada manusia untuk menjadi manusia penuh dan bebas. Alquran sebagai dokumen moral tampaknya akan tetap memberikan arahan kepada otak dan hati manusia sebagai inspirasi terbesar bagi pencarian jalan keluar dari kemelut kemanusiaan pada masa-masa yang akan datang, termasuk untuk bangsa Indonesia. Doktrin tentang keesaan Allah dan kesatuan umat manusia adalah doktrin sentral dalam Alquran. Dari doktin inilah kemudian

7 Fazlur Rahman, Major Themes of the Qur'an, Minneapolis Chicago: Bibliotheca Islamica, 1980), hlm. 37.

${ }^{8}$ lbid,

'Bertrand Russel dan Rosa Russel. 1970. The Prospects of Indusitial Civilization. London: George Allen \& Unwin, hlm. 8. 
mengalir prinsip-prinsip tentang keadilan, persamaan, persaudaraan, dan toleransi. Amat disayangkan, doktrin-doktrin yang begini anggun yang telah berhasil dipraktekkan oleh sosok Muhammad berhadapan dengan golongan elit Quraisy yang sombong dan pongah berkat kekayaan dan kekuasaan yang tergenggam di tangan mereka telah terkubur dalam abu sejarah selama berabad-abad dalam masyarakat dan peradaban umat Islam. Gerakan sosiomoral dalam Islam memang memerlukan kekuasaan politik, sebab tanpa itu pembumian pesan-pesan kemanusiaannya akan mengawang. Sebagaimana dikemukakan oleh Jbnu Taimiyah bahwa cita-cita sosio-moral Islam hanyalah mungkin diterjemahkan ke dalam kenyataan dan terwujud dalam kehidupan masyarakat bilamana dilindungi dan dijaga oleh pedang penolong. Pedang penolong ini tidak lain dari wilayah (organisasi politik), karena itu ia mengatakan bahwa wilaya bagi persoalan (kemasyarakatan) manusia adalah salah satu kewajiban agama yang terpenting .... Agama tidak mungkin tegak kukuh tanpa topangannya. ${ }^{\text {O Doktrin tentang }}$ amrun bi al-ma'ruf (perintah terhadap yang baik) dan nahyun ani al-munkar (pencegahan terhadap yang buruk) (Q.S. 3: 104,110 dan lain-lain) merupakan asas dari bangunan kekuasaan. Akan tetapi perlu dicatat bahwa kekuasaan dalam Islam semata-mata bertujuan untuk menegakkan prinsip-prinsip moral yang diakui bersama. Adapun politik yang semata-mata untuk mempertahankan status quo kekuasaan

${ }^{10}$ Qamaruddin Khan, 1972. The Political Thought of Ibn Taimiyah, Delhi: Adam Publisher and Distributor, hlm. 33 dan 132. yang korup tidak diragukan lagi merupakan perbuatan yang amoral dari sisi perspektif Islam. Bangunan kekuasaan yang tercemar ini sering terlihat di panggung sejarah umat Islam dari dulu sampai sekarang, dan inilah di antara lembaran hitam yang memprihatinkan. Akan tetapi karena Alquran yang juga berfungsi sebagai kriterium pembeda antara kebenaran dan kepalsuan dan sudah merupakan hukum moral dan sejarah tetap di tengah-tengah masyarakat, kekuasaan yang sudah tercemar itu pasti mendapat perlawanan. Kadang-kadang perlawanan itu bersifat demonstratif, tetapi kadang-kadang bersifat diam-diam karena iklim politik menuntut demikian. Ringkasnya adalah bahwa Islam sebagai gerakan pembaruan moral dan pembaruan masyarakat akan tetap menjadi watak agama ini.

Keterlibatan Islam dalam mengubah wajah ruang dan waktu berdasarkan visi moral tertentu merupakan sesuatu yang inheren dalam agama yang dibawa oleh Muhammad sebagai nabi dan rasul terakhir. Perilaku taqwa adalah buah dari iman dan persepsi moral yang tajam. Penjelasan tentang cita-cita kemasyarakatan dalam perspektif di atas, menunjukkan bahwa ide tauhid dan kemanusiaan- ide tentang satu Tuhan dan satu kemanusiaan - yang begitu sentral dalam Alquran telah memberikan ontologi bagi bangunan sebuah masyarakat dan peradaban yang hendak dibangun. Di atas landasan ontologi yang kuat, masyarakat yang hendak dibangun itu haruslah : terbuka, demokratik, toleran, dan damai. Empat ciri utama ini haruslah dijadikan acuan bagi semua gerakan pembaharuan moral dan masyarakat di muka bumi ini. Islam amat mendambakan terwujudnya sebuah bangunan masyarakat yang berwajah ramah dan anggun. Dalam masyarakat dimaksud perbedaan agama, 
Topik : Islam di Indonesia dan Fenomena Disintegrasi Bangsa, Yusdani

ideologi, dan nilai-nilaj budaya, tidak boleh dijadikan penghambat untuk tercapainya cita-cita di atas. Ciri keterbukaan tersebut berangkat dari sifat Alquran sebagai Kitab Suci yang terbuka. la terbuka untuk diterima atau untuk ditolak. Sudah tentu dengan argumen-argumen yang kuat. Yang menolak Alquran tidak harus dikucilkan dari masyarakat. Islam menerima hakikat pluralisme agama dan budaya. Sikap yang harus dikembangkan bukan sikap "monopoli" kebenaran, tetapi sikap saling menghargai dan menghormati. Keterbukaan adalah watak dari sebuah perbedaan yang percaya diri. Sikap terbuka inilah pada masa lampau yang mendorong umat Islam berkenalan secara bebas dengan warisan ruhani hellenisme, Persia dan India. Adapun pada saat umat Islam telah kehilangan rasa percaya diri, sikap keterbukaan inj menjadi semakin redup. Dunia lalu menjadi amat sempit. Kemudian paham persamaan Islam pasti punya dampak terhadap politik. Masyarakat Islam haruslah sebuah masyarakat yang demokratik. Sistem-sistem politik yang otoriter apa lagi yang totaliter harus dinyatakan sebagai sistem yang haram dalam perspektif Islam, apapun alasannya. Hanya dalam sistem politik demokrasilah anggota masyarakat dapat mengembangkan potensi dirinya secara kreatif dan bebas sampai batas-batas yang jauh untuk menjadi manusia penuh.

Dalam sistem demokrasi yang diinginkan Islam, nilai-nilai intelektual dan nilai-nilai spiritual haruslah saling menopang dan saling melengkapi. Masyarakat terdidik tidak boleh tercabik-cabik oleh pertarungan antar postulat "Cogito ergo sum" Rene Descartes dan spiritualisme alGhazali. Setiap kecenderungan ke arah ekstremitas harus dicegah. Demokrasi mesti punya orientasi moral. Inilah barangkali yang dimaksud lqbal sebagai demokrasi spiritual yang menjadi tujuan tertinggi Islam" dalam kehidupan kolektif. Di bawah payung demokrasi spiritual ini masalah keadilan tidak lagi menjadi isu politik karena lawannya berupa ketidakadilan dinilai masyarakat sebagai budaya yang amat rendah dan tidak patut dilakukan oleh manusia beradab. Politik demokratis memerlukan toleransi. Tanpa toleransi sosial, manusia tidak mungkin dapat hidup aman dan damai. Dalam masalah toleransi ini, Islam boleh berbangga diri, khususnya terhadap kelompok non-Muslim. Dalam kasus ini, Islam normatif dan Islam sejarah seakan-akan telah menyatu. Hanyalah pada peristiwa-peristiwa sejarah yang tidak punya dampak besar sajalah umat Islam boleh jadi kurang menghiraukan budaya toleransi inj. Buku-buku sejarah banyak melukiskan ketinggian budi umat Islam dalam masalah tenggang rasa ini. Tetapi yang ironis justru terletak pada kenyataan betapa sukarnya kadang-kadang dikembangkan sifat toleransi internal di kalangan umat Islam sendiri, khususnya dalam politik. Di kawasan ini iklim psikologi umat memang sering rawan. Sudah cukup banyak darah yang tertumpah di kalangan sesama umat Islam, demi kekuasaan. Hal ini semuanya adalah penyakit kanak-kanak yang sukar sembuhnya dalam sejarah Islam. Alangkah idealnya bila dalam masalah politik inj dibudayakan prinsip: "Berbeda dalam persaudaraan dan bersaudara dalam perbedaan". Apabila umat Islam benar-benar mau membangun dalam makna yang komprehensif, prinsip yang

${ }^{11}$ Muhammad lqbal, The Reconstruction ..., hlm. 180 . 
dikemukakan harus dijadikan landasan dalam perilaku dan politik. Dalam tamansari demokrasi spiritual, tidak ada ruang untuk saling menjegal dan menggunting dalam lipatan, sebab pasti akan merobekrobek prinsip-prinsip moral yang merupakan manifestasi iman dalam kehidupan masyarakat. Kemudian untuk menjadikan umat Islam umat al-ilm (komunitas ilmu), tidak ada pilihan lain kecuali budaya toleransi internal diujudkan secara mantap sebagai kemestian sejarah..$^{12}$ Ciri penting terakhir dari sebuah masyarakat Islam ialah agar ia memancarkan wajah damai selaras dengan the very root dari perkataan Islam itu: $s / m$, bermakna damai, sejahtera, selamat. Wajah-wajah yang mengerikan yang berlindung di balik label Islam adalah suatu pengkhianatan dan pencerobohan terhadap maksud Islam itu sendiri. Memperbaiki citra diri ini perlulah dijadikan program utama oleh seluruh gerakan Islam. Hanya sewaktu manghadapi musuh yang garang saja islam perlu bersifat tegas dan pasti. ${ }^{13}$

\section{Islam dan Masa Depan Kehidupan Bangsa Indonesia}

Perkembangan dan prospek bangsa Indonesia pasca- Orde Baru akan membawa kepada berbagai implikasi. Khusus bagi perkembangan diskursus pemikiran dan praktek Islam itu sendiri. Untuk itu para pemikir dan aktivis politik Islam perlu (1) mereformulasikan dasar-dasar teologis ke dalam bidang politik secara cerdas; (2) h.m. 70-71.

${ }^{12}$ Ahmad Syafil Maarif, Membumikan ....

13 Ibid. hlm. 71. mendefinisi ulang cita-cita politik; dan (3)merumuskan kembali strategi perjuangan politik Islam. Akan tetapi sebagaimana telah diterangkan pada pembicaraan sebelumnya, bahwa persoalan dasar yang dihadapi politik Islam dalam hubungannya dengan konstruksi negara dan bangsa indonesia adalah adanya kesulitan untuk membangun sintesa yang memungkinkan. Faktor utama yang menyebabkan kemandekan politik di Indonesia selama Orde Lama dan awal Orde Baru adalah keinginan para pemimpin politjk Islam untuk membangun hubungan Islam dan negara secara legalistik dan formalistik. Bahkan fenomena tersebut dapat juga diamati dengan munculnya keinginan komunitas muslim tertentu untuk memberlakukan kembali Piagam Jakarta dalam konstruk negara Indonesia. Keinginan politik seperti ini sekalipun sah-sah saja dalam perspektif demokratisasi tetapi secara substansial apakah dapat menjawab persoalan kenegaraan Indonesia yang sedang menghadapi disintegrasi? Oleh karena itu, apakah tidak lebih baik dalam konteks Indonesia sekarang sebenarnya perlu dikembangkan pemikiran bahwa Islam lebih mementingkan terbentuknya sebuah tatanan masyarakat yang baik, yaitu masyarakat yang merefleksikan substansi ajaran Islam seperti prinsip keadilan, egalitarianisme, partisipasi, musyawarah dan sebagainya. Sejauh mekanisme tatanan kemasyarakatan dan negara diatur dengan prinsipprinsip dasar seperti itu, yang menurut Robert N. Bellah ciri-ciri itu terdapat pada negara- kota Muhammad di Madinah. ${ }^{14}$

14 Robert N. Bellah, 1991. Beyond Belief : Essays on Religion in a Post Traditionalist World, Berkeley dan Los Angeles: University of California Press, hlm. 151. 
Topik : Islam di Indonesia dan Fenomena Disintegrasi Bangsa, Yusdani

Dengan demikian dasar-dasar baru politik yang dikembangkan lebih berorientasi pada nilai ( substansialistik) daripada bentuk dan simbol ( formalistik/legalistik).

Implikasi dari formulasi teologis politik di atas adalah bahwa cita-cita politik Islam adalah terbentuknya sebuah sistem sosial dan politik yang merefleksikan, atau sesuai dengan, nilai-nilai Islam. Karena prinsip-prinsip etis politik Islam berbicara tentang keadilan ( $a d l)$, musyawarah (syura), persamaan (musawa), bentuk sistem kenegaraan yang secara substantif mencerminkan nilaj-nilai Islam adalah demokrasi. Untuk itu, perumusan cita-cita politik Islam masa depan di Indonesia berujung pada (1) terbentuknya mekanisme politik yang sifatnya egaliter dan demokratis; dan (2) berlakunya proses ekonomi yang lebih kurang equitable. ${ }^{15}$ Kenyataan bahwa jalan untuk menuju Indonesia yang demokratis dan egaliter masih panjang, hal itu harus dilihat sebagai sesuatu yang memprihatinkan seluruh bangsa Indonesia. Karena watak cita-cita politik Islam yang universal itu, pendekatannya pun harus bersifat integratif, dengan melibatkan seluruh kekuatan bangsa. Dengan demikian, cita-cita untuk menegakkan nilai-nilai demokrasi hendaknya dilakukan di dalam kerangka sistem politik yang ada. ${ }^{16}$ Berpangkal tolak dari definisi dan cita-cita politik Islam, strategi perjuangan politik Islam yang dikembangkan lebih bersifat inklusif, integratif, dan diversifikatif yang dirumus-

${ }^{15}$ Bosco Carvalo dan Dasrizal (Ed.). 1983. Aspirasi Umat Islam Indonesia, Jakarta: Leppenas.

${ }^{16}$ Munawir Sjadzali. 1990. Islam dan Tata Negara Ajaran, Sejarah dan Pemikiran, Jakarta: Ul-Press. kan dalam kerangka cita-cita masyarakat Indonesia secara keseluruhan. Dapat dikatakan bahwa agenda ini meliputi soalsoal demokratisasi, toleransi politik dan agama, egalitarranisme sosial-ekonomi dan partisipasi politik. Hal ini semua menunjukkan adanya sebuah transformasi yang cukup berarti dalam pemikiran dan praktek politik Islam. Semua itu, baik pada tatanan teologis, cita-cita politik, dan strategi pendekatannya, ditujukan untuk menghadirkan sebuah sintesa yang memungkinkan antara Islam dan politik. Dalam konteks yang lebih empirik, intelektualisme dan aktivisme politik dikembangkan untuk menghadirkan sebuah Islam politik yang lebih inklusif dan integratif dalam hubungannya dengan konstruk negara Indonesia yang ada.

\section{Penutup}

Untuk menuju politik Indonesia yang demokratis dan egaliter masih panjang, hal itu hendaklah dilihat sebagai sesuatu yang memprihatinkan seluruh bangsa Indonesia. Oleh karena itu, cita-cita politik muslim yang universal itu membutuhkan pendekatan substantif yang bersifat integratif dan diversifikatjf dengan melibatkan seluruh kekuatan bangsa. Dengan demikian, citacita untuk menegakkan nilai-nilai demokrasi hendaknya dilakukan dalam kerangka sistem politik yang ada. Di samping itu, untuk mencapai cita-cita politik muslim, strategi perjuangan yang dikembangkan hendaklah lebih bersifat inklusif, integratif dan diversifikatif yang diformulasikan dalam kerangka cita-cita masyarakat Indonesia secara keseluruhan. Harapan semua pihak tentunya tidak lain agar Demokrasi Indonesia masa depan pandai-pandai belajar dari pengalaman masa lalu, sehing- 
ga budaya politik tidak lagi melahirkan akrobat-akrobat politik, seperti yang dipamerkan oleh beberapa tokoh politik, beberapa waktu silam.

Oleh karena itu, berdirinya banyak partai politik dengan berbagai asasnya masing-masing di era reformasi ini dalam perspektif alam demokrasi memang positif, akan tetapi perlu dihindari ekspediensi dan sikap-sikap akrobat-akrobat petualang politik yang secara moral belum tentu benar dan baik bagi bangsa ini. Partai politik-partai politik muslim di Indonesia era reformasi harus menduduki garda terdepan dalam membela prinsip-prinsip demokrasi dalam politik dan menghindarkan diri dari sikap eksklusivitas. Karena itu para pemikir dan aktivis politik muslim perlu memtormulasikan etika dan moralitas teologisnya ke dalam lapangan politik, mengkaji ulang cita-cita politik Islam dan meninjau kembali strategi perjuangan pemimpin politik muslim untuk menyongsong Indonesia yang dicita-citakan bersama.

\section{Daftar Pustaka}

Ali, Fachry dan Bahtiar Effendy. 1990. Merambah Jalan Baru Islam Rekonstruksi Masa Orde Baru. Bandung : Mizan.
Bellah, Robert N.. 1991. Beyond Belief : Essays on Religion in a Post -Traditionalist World. Berkeley dan Los Anḡeles: University of California Press.

Binder, Leonard. 1963. Religion and Politics in Pakistan. Berkeley dan Los Angeles: University of California Press.

Carvalo, Bosco dan Dasrizal. (Ed.).t983. Aspirasi Umat Islam Indonesia. Jakarta : Leppenas.

Effendy, Bahtiar. 1995. "Islam dan Negara Transformasi Pemikiran dan Praktek Politik Islam di Indonesia." Dalam Prisma 5 Mei 1995. HIm. 328.

1998.Islam dan Negara: Transformasi Pemikiran dan Praktik Politik Islam di Indonesia. Jakarta : Paramadina dan lbnu Sina

Gibb, H.A.R. (Ed.) .1932. Moslem Whither Islam : A Survey of Modern Movements in the World. London: Victor Gollancz Ltd.

Iqbal, Muhammad. 1972. The Reconstruction of Religious Thought in Islam. Lahore: Muhammad Ashraf. 
Topik : Islam di Indonesia dan Fenomena Disintegrasi Bangsa, Yusdani

Khan, Qamaruddin. 1972. The Political Thought of Ibn Taimiyah. Delhi: Adam Publisher and Distributor.

Ma'arif, Ahmad Syafi'i. 1995. Membumikan Islam. Yogyakarta: Pustaka Pelajar.

Musa, Muhammad Yusuf. 1963. Nizam alHukm fi al-Islam. Cairo: Dar al-Kitab al-Arabi.

Rahman, Fazlur. 1980. Major Themes of the Qur'an. Minneapolis Chicago: Bibliotheca Islamica.
Russel, Bertrand dan Rosa Russel. 1970. The Prospects of Industial Civilization. London: George Allen \& Unwin.

Sjadzali, Munawir. 1990. Islam dan Tata Negara Ajaran, Sejarah dan Pemikiran. Jakarta: UI-Press.

Surur, Taha Abd. al-Baqi. 1972. Dawla alQur'an. Cairo: Dar Nadha Misr.

Syamsuddin, M. Din.2001. Islam dan Politik Era Orde Baru. Pengantar Bahtiar Effendy. Jakarta : Logos. 